\title{
Firm Level Determinants and Dividend Policy in Pakistan
}

\author{
Muhammad Ali Chohan, Suresh Ramakrishnan, Saleh Ahmad Al-Harthi, Shamaila Butt
}

\begin{abstract}
Dividend policy is a challenge in the field of corporate finance. This paper finds out the important factors of dividend policy of Pakistani listed firms. The current paper aims to examine the impact of firm specific factors of dividend policy in Pakistan. The factors examine in this study are profitability, free cash flow, firm size, liquidity, financial leverage, investment opportunities and corporate tax. The data are collected from annual reports and Pakistan Stock Exchange. To accomplish the objective, financial data from 2000 to 2017 are collected and analyzed to examine the impact of firm level determinants on dividend payout. This paper used pooled ordinary least squares model and fixed effect model. The findings reveal that firm specific factors have significant influence on dividend policy in Pakistan. The profitability of firm and corporate tax has positive influence, whereas firm size and investment opportunities have negative impact on dividend payout. The implication of current research is useful for board of directors and managers to decide the appropriate dividend policy for firm. This study is also helpful for investors about investment decision. This research is a contribution to the existing body of knowledge about the determinants that influence dividend policy of Pakistani listed firms. Future researcher should use the same phenomenon in different emerging economies using the different approach to reduce the dividend puzzle in the field of corporate finance.
\end{abstract}

Index Terms: Dividend Payout; Firms Specific; Dividend Puzzle

\section{INTRODUCTION}

Dividend policy and determinants of dividend policy remains a much-studied topic in the field of corporate finance literature. Even though many similarities exist amongst the several verdicts involving dividend policy factors. The differences in empirical findings emerges not only because of contextual differences between developed and emerging economies but also because of research methodologies used to identify the significant factors of dividend policy. Past studies found that it is a common question that arises why firms pay dividends? This question is focus of research since long time and after a dividend puzzle it becomes a burning topic as a question for further discussion. [1] and [2] provides evidence to reduce the agency conflict, firms should use dividend payout policy. The findings reveal that if companies

Revised Manuscript Received on September 22, 2019.

Muhammad Ali Chohan, Azman Hashim International Business School, Universiti Teknologi Malaysia, 81030 Johor Bahru, Johor, Malaysia

Suresh Ramakrishnan, Associate Professor, Azman Hashim International Business School, Universiti Teknologi Malaysia, 81030 Johor Bahru, Johor, Malaysia

Saleh Ahmad Al-Harthi, Faculty of Administrative Sciences, Najran University, Saudi Arabia.

Shamaila Butt, Azman Hashim International Business School, Universiti Teknologi Malaysia, 81030 Johor Bahru, Johor, Malaysia will not pay dividends, the managers will use firm resources for their personal benefits. [1] found that firms can reduce the control of managers over the resources by paying dividends. Influential study of [3] referred dividend policy as a dividend puzzle, "The harder we look at the dividend picture the more it seems like a puzzle, with pieces that just don't fit together". [4] discussed about the top ten problems in advance corporate finance which are unresolved, dividend policy is one of among those problems.

It is a consensus that there is no single explanation of the dividend policy about theories and determinants. Some studies debated the factors of dividend policy in recent times are [5], [6], and [7]. Earlier research focused mostly on developed markets, while the limited evidences are found on the factors of dividend policy in emerging countries $[8,9]$. Consequently, the controversial findings of earlier studies on dividend policy exert influence on researchers to examine the important factors of dividend policy in Pakistan. Hence, this paper aims to investigate the significant determinants that effect the dividend policy of Pakistani non-financial listed firms and identify the importance of significant factors on the dividend policy of Pakistani listed firms.

Pakistan Stock Exchange (KSE) listed firms have complete authority to decide dividend policy except that Section 241 of Companies Act of 2017. This section obliges them to pay dividend out of their profits. Furthermore, no specific procedures have been formulated by Security and Exchange Commission of Pakistan (SECP) or any other legal institution for the business sector that stipulates the dividend payout policy. In addition, the tax system in Pakistan is totally different as compared to developed countries. Thus, there is a prospect of differences in the tax system that may affect the dividend payout in Pakistan. Since, adverse tax management of dividend income is a more thoughtful issue in Pakistan than developed countries such as United States. Therefore, this study focuses on the dividend policy of the non-financial firms of Pakistan to fill this gap in the literature to investigate the influence of firm specific determinants on dividend policy. This study might be helped the current and potential shareholders in decision making for their investment. The intent of the study is to examine the significant factors of dividend policy of Pakistani listed firms.

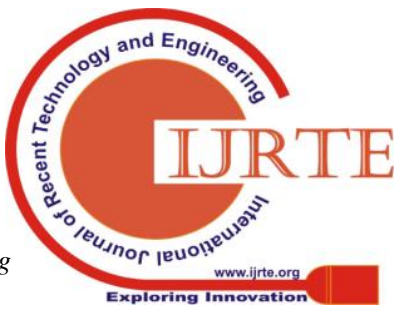




\section{LITERATURE REVIEW}

Previous findings have presented explanations through theories for dividend payout based dividend policy determinants [10-12]. [12] emphasize on this argument that one theory or an aspect is unlikely to describe the dividend policy. [1] and [13] claimed that theory bird in the hand explains that shareholders desire to receive dividend on capital gains. They reasoned that the dividend payout is not as much of risky as the capital gain. Consequently, prosperity of dividend paying firm grows if dividend payout is increased. [14] proposed the irrelevance theory of dividend which explains that dividend policy had no effect on value of that firm and investors wealth. Thus, it was considered as irrelevant in perfect market. It had remained a thought that the costs of dividend payment reduce their wealth with the tax effect. Consequently, shareholders desire to receive capital gain to dividend pay out, that is supported by tax preference theory. [15] Dividend payout is altered not only by the internal factors of firm i.e. profitability, investment opportunity and liquidity but influence also by the external factors like growth and tax rate. These external factors show a substantial role in dividend policy. [16] found that dividend policy is determined by profitability, investment opportunities and financial leverage. Large size and profitable firms' payout more dividend. [17] explored that profitability of firm, business tax and free cash flow are positive related to dividend policy. Investment opportunities have negative relationship with dividend policy.

[18] elucidates that market liquidity and ownership concentration have positive relation with dividend policy while financial leverage and investment opportunities have negative relationship with dividend policy. The dividend policy has also influenced by market capitalization and firm size which reveal that companies choose to invest in assets afore dividend payment to investors. [19] elaborated the determinants of dividend policy which shows that the liquidity and beta as a substantial determinant of the dividend policy. Alternatively, free cash flow, tax, growth in sales and investment opportunities does not influence dividend policy. [20] demonstrate the influence of cash flow, growth opportunities, size, government ownership, financial leverage, growth rate, profitability and business risk on dividend policy. They found that the empirical findings reveal government ownership, size and profitability are positive affecting dividend policy. Despite the fact, financial leverage negatively affected dividend policy. It also shows that the firms payout dividend to mitigate the agency conflict and to sustain firms repute, since that a limited protection for outside investors. To keep the status firm dividend decision making is highly depends on firm profitability, which shows that the firm believes to alter the dividend policy regularly should not follow the long-term dividend policy.

[21] explore the elementary determinants of dividend policy i.e. ownership structure, financial leverage, firm liquidity, growth, and profitability of firm. The research found that the financial leverage and liquidity of firm are the significant determinants of dividend policy. [22] investigates the factors affecting dividend policy of firms and results reveal that profitability has positive associated to dividend policy. However, the reverse association found among beta, price earnings ratio, and financial leverage. Firm size and retained earning do not have effect on dividend policy. [23] analysed the dividend policy in Pakistan and determined that cash flow and profitability have been positive related to dividend policy. However, the separate ownership, firm size, sensitivity of cash flow, and financial leverage have been found negative associated to dividend policy. The study examined that managerial ownership, individual ownership, cash flow, and firm size are significant determining factors of dividend policy. However, profitability and financial leverage do not play a significant role in determining dividend policy of firms.

[24] illustrates the factors of dividend payout of Sri Lanka companies. They found that investment opportunities, past dividends, profitability and dividend premium are important determining factors of dividend payout. The research study also uncovered that investment opportunities are negative associated to dividend policy. Conversely, profitability, past dividends and dividend premium are negative associated to dividend payout. Furthermore, [25] found that profitability, past dividends, investor preferences and investment opportunities are significant determinates of dividend policy and all are positive associated to dividend policy. Grounded on extensive literature, this research study anticipates that profitability, free cash flow, firm size, financial leverage, liquidity, investment opportunities and corporate tax has an impact on dividend payout of non-financial Pakistani listed firms. Table 1 displays the summary of selected past studies literature.

Table 1 Summary of Selected Past Studies on Firm Specific Variables and Dividend Policy

\begin{tabular}{|l|c|c|l|l|}
\hline \multicolumn{1}{|c|}{ Author } & Period/Annual & $\begin{array}{c}\text { Region/ } \\
\text { Country }\end{array}$ & \multicolumn{1}{c|}{ Methods } & \multicolumn{1}{c|}{ Results } \\
\hline Dewasiri et al [24] & $2010-2016$ & Sri Lanka & $\begin{array}{l}\text { Binary Logistic } \\
\text { Regression and Fixed } \\
\text { Effect Panel Regression }\end{array}$ & $\begin{array}{l}\text { Past dividends, dividend premium, } \\
\text { profitability, and investment } \\
\text { opportunities, show significant impact } \\
\text { on dividend policy }\end{array}$ \\
\hline Baker et al [25] & $2010-2016$ & Sri Lanka & Triangulation Approach & $\begin{array}{l}\text { Past dividends, investor preferences, } \\
\text { investment opportunities and } \\
\text { profitability show extensive impact on } \\
\text { dividend policy }\end{array}$ \\
\hline
\end{tabular}




\begin{tabular}{|c|c|c|c|c|}
\hline Author & Period/Annual & $\begin{array}{l}\text { Region/ } \\
\text { Country }\end{array}$ & Methods & Results \\
\hline $\begin{array}{l}\text { Singla and } \\
\text { Samanta [26] }\end{array}$ & $2011-2016$ & India & $\begin{array}{l}\text { Panel Fixed and Random } \\
\text { Effect Regression }\end{array}$ & $\begin{array}{l}\text { Profitability, life cycle, firm size, and } \\
\text { cash flow are significant. }\end{array}$ \\
\hline $\begin{array}{l}\text { Hudiwijono et al } \\
{[27]}\end{array}$ & $2010-2016$ & Indonesia & $\begin{array}{l}\text { Multiple } \quad \text { Regression } \\
\text { Analysis }\end{array}$ & $\begin{array}{l}\text { Profitability, financial leverage, } \\
\text { liquidity, firm size, free cash flow, } \\
\text { growth of firm, and business risk are } \\
\text { substantial factors }\end{array}$ \\
\hline $\begin{array}{ll}\text { Gangill and } & \text { and } \\
\text { Nathani [28] }\end{array}$ & $2007-2016$ & India & $\begin{array}{l}\text { Multiple } \quad \text { Regression } \\
\text { Analysis }\end{array}$ & $\begin{array}{l}\text { Profitability and growth opportunities } \\
\text { are significant }\end{array}$ \\
\hline $\begin{array}{l}\text { Yusof and Ismail } \\
\text { [29] }\end{array}$ & $2006-2010$ & Malaysia & $\begin{array}{l}\text { Pooled OLS, Fixed and } \\
\text { Random Effect Panel } \\
\text { Regression }\end{array}$ & $\begin{array}{l}\text { Earnings, firm debt, firm size, } \\
\text { investment opportunities and large } \\
\text { shareholders are significant. }\end{array}$ \\
\hline Arko et al [30] & $1997-2007$ & $\begin{array}{l}\text { Sub-Sahar } \\
\text { an Africa }\end{array}$ & $\begin{array}{l}\text { Generalized } r \text { Least } \\
\text { Squares and Probit } \\
\text { Model. }\end{array}$ & $\begin{array}{l}\text { Profitability, leverage, investment } \\
\text { opportunities, taxation, risk and } \\
\text { institutional shareholding are } \\
\text { influential. }\end{array}$ \\
\hline $\begin{array}{l}\text { Abor and Bopkin } \\
\text { [31] }\end{array}$ & 1990-2006 & $\begin{array}{l}34 \\
\text { emerging } \\
\text { countries }\end{array}$ & $\begin{array}{lll}\text { Fixed } & \text { Effects } & \text { Panel } \\
\text { Model } & & \end{array}$ & $\begin{array}{l}\text { Profitability, stock market capitalization } \\
\text { and investment opportunities are } \\
\text { significant. }\end{array}$ \\
\hline $\begin{array}{l}\text { Ahmed and Javid } \\
{[18]}\end{array}$ & $2001-2006$ & Pakistan & Panel Regression & $\begin{array}{l}\text { Net earnings, market liquidity, } \\
\text { ownership concentration, investment } \\
\text { opportunities, market capitalization, } \\
\text { leverage, and size of the firms are } \\
\text { significant. }\end{array}$ \\
\hline Al-Malkawi [32] & $1989-2000$ & Jordan & Tobit Model & $\begin{array}{l}\text { Size, age, and profitability are } \\
\text { significant. }\end{array}$ \\
\hline $\begin{array}{l}\text { Amidu and Abor } \\
{[17]}\end{array}$ & $1998-2003$ & Ghana & OLS Model & $\begin{array}{l}\text { Profitability, growth in sales, cash flow, } \\
\text { and investment opportunities are } \\
\text { significant. }\end{array}$ \\
\hline
\end{tabular}

Source: Authors' compilation

\section{METHODOLOGY}

This research paper investigates the determinants of dividend payout in Pakistan. Thus, to get better understanding of dividend payout in Pakistan, this research study investigates the dividend payout of non-financial listed firms on PSX during the period from 2000-2017. This research employs sample period from 2000-2017, which is selected due to various reasons specifically in 2000 strict and prevalent guidelines formulated by SECP to protect investors. In addition, sample period from 2000 to 2017 is characterized by a significant economic and social changes which inevitably have an influence on dividend policy. Hence, the research used census sampling that is very flexible and generates results which represents the whole population. This research excludes the financial firms because of its unlike behavior as compare to non-financial firms. The study includes firms which are listed on Pakistan Stock Exchange and dividend paying as well. The research focused on secondary data, which was extracted from various reliable sources i.e. State Bank of Pakistan, Pakistan Stock Exchange, and annual reports.

This research study employs the panel data techniques regarding the nature of the data. According to [33], panel data technique provides more variability and degree of freedom that reduces the collinearity problems amongst independent variables. Furthermore, panel data have the ability to capture the special effects that are not obvious in cross-section or time series data [34]. The dataset comprises in this study are the ones that distribute dividend includes 134 firms. The study used unbalanced dataset to capture the accuracy of results. Moreover, the firms which have minimum data availability time period, is included in the unbalanced panel.

Table 2 Variables Proxy and Data Sources

\begin{tabular}{|c|c|c|}
\hline Variable & Proxy & Source of Data \\
\hline DY & $\begin{array}{l}\text { Dividend Per } \\
\text { Share/ Share } \\
\text { Price }\end{array}$ & $\begin{array}{l}\text { SBP, PSX, and Annual } \\
\text { Reports }\end{array}$ \\
\hline PROF & $\begin{array}{l}\text { Net Income/Total } \\
\text { Equity }\end{array}$ & $\begin{array}{l}\text { SBP, PSX, and Annual } \\
\text { Reports }\end{array}$ \\
\hline FCF & $\begin{array}{l}\text { Operating Cash } \\
\text { Flow/Total Asset }\end{array}$ & $\begin{array}{l}\text { SBP, PSX, and Annual } \\
\text { Reports }\end{array}$ \\
\hline SIZE & $\begin{array}{l}\text { Log Value of } \\
\text { Total Assets }\end{array}$ & $\begin{array}{l}\text { SBP, PSX, and Annual } \\
\text { Reports }\end{array}$ \\
\hline LIQR & $\begin{array}{l}\text { Current } \\
\text { Assets/Current } \\
\text { Liabilities }\end{array}$ & $\begin{array}{l}\text { SBP, PSX, and Annual } \\
\text { Reports }\end{array}$ \\
\hline LEVR & $\begin{array}{l}\text { Total Debt/Total } \\
\text { Equity }\end{array}$ & $\begin{array}{l}\text { SBP, PSX, and Annual } \\
\text { Reports }\end{array}$ \\
\hline
\end{tabular}




\begin{tabular}{|l|l|l|}
\hline Variable & Proxy & Source of Data \\
\hline MTBR & $\begin{array}{l}\text { Market Value Per } \\
\text { Share/Book } \\
\text { Value Per Share }\end{array}$ & $\begin{array}{l}\text { SBP, PSX, and Annual } \\
\text { Reports }\end{array}$ \\
\hline TAX & $\begin{array}{l}\text { Corporate } \\
\text { Tax/Income } \\
\text { Before Tax }\end{array}$ & $\begin{array}{l}\text { SBP, PSX, and Annual } \\
\text { Reports }\end{array}$ \\
\hline
\end{tabular}

Note: DY represents dividend yield, PROF represents profitability, FCF represents free cash flow, SIZE represents size of the firm, LIQR shows liquidity, LEVR shows the financial leverage, MTBR shows investment opportunities and TAX represents corporate tax, SBP shows state bank of Pakistan, PSX represent Pakistan stock exchange.

Models are estimated by using pooled ordinary least squares (pooled OLS) regressions and fixed effect to explain the significant factors of dividend policy across non-financial Pakistani listed firms. Regression models employed in current research are estimated by using Gretl statistical package. Dividend policy factors are observed using dividend yield as a dependent variable. In current research, for selection of most suitable technique, the study used LM test. The verdicts of LM test is significant and rejects the null hypothesis, which reveal that results of pooled OLS regression is rejected. In addition, for selection of appropriate panel model, the study used the Hausman test in which the $\mathrm{p}$ value is $<0.05$, $T$ null hypothesis of the suitability of random effect model is rejected. Hence, the current research proceeds with the fixed effect for the analysis.

The research elucidates the factors of dividend policy based on pooled OLS regression and fixed effect analysis. Thus, equation 3.1 offers the anticipated relationship between firm specific factors and dividend yield based on pooled OLS regression.

$$
\begin{aligned}
& D Y_{i t}=\alpha+\beta_{1}(P R O F)_{i t}+\beta_{2}(F C F)_{i t} \\
& +\beta_{3}(\text { SIZE })_{i t}+\beta_{4}(L I Q R)_{i t}+\beta_{5}(L E V R)_{i t} \\
& +\beta_{6}(M T B R)_{i t}+\beta_{7}(T A X)_{i t}+\varepsilon_{i t}
\end{aligned}
$$

Where, $\mathrm{DY}_{\text {it }}$ is firm dividend yield of firm i in time $t, \alpha$ is the intercept of the equation, with firm level determinants are (PROF) profitability, (FCF) free cash flow, (SIZE) size, (LIQR) liquidity, (LEVR) financial leverage, (MTBR) investment opportunities, (TAX) corporate tax and $\varepsilon_{\text {it }}$ shows the error term. Furthermore Equation (3.2) shows the following expression;

$D Y_{i t}=\alpha+\beta_{1}(P R O F)_{i t}+\beta_{2}(F C F)_{i t}$

$+\beta_{3}(S I Z E)_{i t}+\beta_{4}(L I Q R)_{i t}+\beta_{5}(L E V R)_{i t}$

$+\beta_{6}(M T B R)_{i t}+\beta_{7}(T A X)_{i t}+\mu_{i}+\varepsilon_{i t}$

Where, $D Y_{\text {it }}$ is firm dividend yield of firm $i$ in time $t, \alpha$ is the intercept of the equation, with firm level determinants are (PROF) profitability, (FCF) free cash flow, (SIZE) size, (LIQR) liquidity, (LEVR) financial leverage, (MTBR) investment opportunities, and (TAX) corporate tax. The firm fixed effects $\mu_{i}$ control for cross sectional differences in the firm characteristics and $\varepsilon_{\mathrm{it}}$ shows the error term.

\section{RESULT AND DISCUSSION}

The study examines the preliminary analysis, such as, screening of data and diagnostic summary i.e. collinearity, normality and heteroscedasticity. Panel regression models are estimated by using pooled ordinary least squares regression and fixed effect model.

Table 3 Descriptive Statistics

\begin{tabular}{|l|c|c|c|c|}
\hline Variable & $\begin{array}{c}\text { Mea } \\
\mathrm{n}\end{array}$ & $\begin{array}{c}\text { Standard } \\
\text { Deviation }\end{array}$ & Minimum & $\begin{array}{c}\text { Maximu } \\
\mathrm{m}\end{array}$ \\
\hline DY & 6.64 & 7.81 & 0.00 & 114.70 \\
\hline PROF & 0.09 & 1.57 & -47.51 & 9.88 \\
\hline FCF & 0.18 & 0.27 & -1.52 & 1.88 \\
\hline SIZE & 15.22 & 1.56 & 9.83 & 19.73 \\
\hline LIQR & 1.88 & 4.74 & 0.10 & 138.50 \\
\hline LEVR & 0.45 & 1.04 & -8.50 & 33.28 \\
\hline MTBR & 2.17 & 6.77 & -38.49 & 198.50 \\
\hline TAX & 0.40 & 8.22 & -50.94 & 333.90 \\
\hline
\end{tabular}

Table 3 summarized the descriptive summary of all variables. Mean of dividend yield is 6.64 with maximum 114.7 and minimum of zero and standard deviation is 7.81 . Profitability mean is 0.09 with standard deviation 1.57, minimum -47.5 and maximum 9.88. Free cash flow ranges from minimum -1.52 to maximum 1.88 with mean value 0.18 and standard deviation 0.27 . Firm size mean is 15.22 with standard deviation 1.56 , maximum 19.73 and minimum 9.83. Liquidity shows mean value 1.88 with standard deviation 4.74, minimum 0.10 and maximum 138.50 . Financial leverage reveals mean value of 0.45 with minimum -8.50, maximum 33.28 and standard deviation 1.04. Investment opportunities ranging from -38.49 to 198.50 with mean values 2.17 and standard deviation 6.77. Corporate tax mean is 0.40 with standard deviation 8.22 , minimum -50.94 and maximum 333.90. The standard deviation show that each variable is deviated from its mean value.

Analysis of correlation matrix in table 4 and variance inflation factor (VIF) in table 5 show that the data are free from multi-collinearity. As panel data suffer from the issue of heteroskedasticity thus, the robust estimation confirms that data set are free from issue of heteroskedasticity [29]. Hence, to mitigate the autocorrelation and heteroskedasticity in panel, robust estimates are used [26]. To diminish the abnormality of data set, this research took natural logarithm of variables.

Table 4 Correlation Matrix

\begin{tabular}{|l|l|l|l|l|l|l|l|l|}
\hline & DY & PROF & FCF & SIZE & LIQR & LEV & MTB & TAX \\
\hline DY & 1.000 & & & & & & & \\
\hline PROF & 0.046 & 1.000 & & & & & & \\
\hline FCF & -0.031 & 0.241 & 1.000 & & & & & \\
\hline SIZE & -0.086 & 0.007 & -0.140 & 1.000 & & & & \\
\hline LIQR & 0.057 & 0.158 & -0.015 & -0.073 & 1.000 & & & \\
\hline LEV & 0.024 & -0.181 & -0.101 & 0.050 & -0.492 & 1.000 & & \\
\hline MTB & -0.246 & 0.476 & 0.206 & 0.144 & 0.006 & -0.112 & 1.000 & \\
\hline TAX & 0.035 & -0.072 & -0.010 & -0.041 & -0.121 & -0.082 & 0.154 & 1.000 \\
\hline
\end{tabular}

Note: Table displays the correlation among the variables. DY, dividend yield; PROF, profitability; FCF, free cash flow; SIZE, firm size; LIQR, liquidity; LEVR, financial leverage; MTBR, investment opportunities; TAX, corporate tax 
Table 5 Variance Inflation Factor

\begin{tabular}{|c|c|c|c|c|c|c|}
\hline PROF & FCF & SIZE & LIQR & LEVR & MTBR & TAX \\
\hline 1.433 & 1.119 & 1.081 & 1.712 & 1.784 & 1.401 & 1.079 \\
\hline
\end{tabular}

Table 6 show that models are significant at $1 \%$ level in explaining the dividend policy. Profitability, firm size, investment opportunities, and corporate tax are significant determinants of dividend policy based on fixed effect model. None of the other variables reached significance. In table 6 findings of the research are in detail and F-value statistics of models show the model fitness and significance.

Table 6 Determinants of Dividend Policy

\begin{tabular}{|l|l|l|}
\hline Variables & Pooled OLS & Fixed Effect \\
\hline Const & $2.063(0.000) * * *$ & $4.031(0.000)^{* * *}$ \\
\hline PROF & $0.150(0.013) * *$ & $0.137(0.000)^{* * *}$ \\
\hline FCF & $0.004(0.886)$ & $-0.011(0.670)$ \\
\hline SIZE & $-0.015(0.653)$ & $\begin{array}{l}* \\
\end{array}$ \\
\hline LIQR & $0.089(0.442)$ & $0.053(0.593)$ \\
\hline LEVR & $0.007(0.841)$ & $0.009(0.756)$ \\
\hline MTBR & $-0.252(0.000)^{* *}$ & $-0.404(0.000)^{* *}$ \\
& $*$ & $*$ \\
\hline TAX & $-0.021(0.696)$ & $0.078(0.051)^{*}$ \\
\hline F-Stat & 5.475 & 15.954 \\
\hline P-value & $0.000 * * *$ & $0.000 * * *$ \\
\hline
\end{tabular}

Note: The significance level as follow, *** significant at the $1 \%$ level, $* *$ significant at the $5 \%$ level, and $*$ significant at the $10 \%$ level.

This research explores the significant factors of dividend policy in Pakistan. The study analyzed the results of research objectives. Based on the objective, the study examines the determinants of dividend policy. Profitability is positive significant factor of dividend policy of non-financial Pakistani listed firms. The finding is consistent with the earlier studies [24-26]. Findings of profitability supports signaling theory $[35,36]$ that when firms are more profitable, it will pay more dividend to investors. Firm size is negative related to dividend policy which reveal that large firms desire to pay a lesser amount of dividend, which is consistent with the results of [18]. Findings are followed by life cycle theory, that demonstrates that companies have more opportunities which are in need of more funds for developments. Thus it pays a lesser amount of dividend to investors [18, 37]. The results show that firms with more investment opportunities pay a smaller amount of dividend in Pakistan for the reason that firms having more investment opportunities are willing to hold their earnings to invest in projects, as an alternative of paying dividend to investors. The results of the research confirm the agency cost and free cash flow theory of dividend policy. Corporate tax displays a positive relationship to dividend policy, which shows that companies with higher tax rates are paying more dividends. Findings of the research corroborates the findings of $[17,38]$ that also found positive relationship among corporate tax and dividend policy.

\section{Conclusion}

This research aims to investigate that the firm level determinants have significant impact on dividend policy in
Pakistan. This study is beneficial for investors, managers and researchers. The study shows that the shareholders are concerned to get more dividend and consider profitability, firm size, investment opportunities and corporate tax before investing in the specific firm. Managers of the firm should also focus on all those factors which are influencing the dividend policy before formulating dividend policy. Future academicians and researchers should use propensity to pay dividend and dividend payment at the same time when examining the significant determinants of dividend policy in other countries to contribute for a consensus on dividend puzzle.

\section{References}

[1] J. Lintner, "<Distribution of Incomes of Corporations Among Dividends, Retained Earnings, and Taxes.pdf $>$," in Papers and Proceedings of the Sixty-eighth Annual Meeting of the American Economic Association, 1956, vol. 42, no. 2, pp. 97-113: The American Economic Review.

[2] M. S. Rozeff, "<1982 Growth,Beta and Agency Costs as Determinants of Dividend Payout Ratios.pdf>," The Journal of Financial Research, vol. V, no. 3, 1982.

[3] F. Black, "<The dividend puzzle>," The Journal of Portfolio Managaement, 1976.

[4] R. A. Brealey, S. C. Myers, and F. Allen, "Principles of Corporate Finance (McGraw-Hill, New York)," 2005.

[5] B. Al-Najjar, "<The inter-relationship between capital structure and dividend policy.pdf>," International Review of Applied Economics, vol. 25, no. 2, pp. 209-224, 2011

[6] T. Patra, S. Poshakwale, and K. Ow-Yong, "<Determinants of corporate dividend policy in Greece.pdf>," Applied Financial Economics, vol. 22, no. 13 , pp. $1079-1087,2012$

[7] R. B. Kumar and K. Sujit, "Determinants of dividends among Indian firms-An empirical study," Cogent Economics \& Finance, vol. 6, no. 1, p. $1423895,2018$.

[8] A. Fatemi and R. Bildik, "Yes, dividends are disappearing: Worldwide evidence," Journal of Banking \& Finance, vol. 36, no. 3, pp. 662-677, 2012.

[9] N. B. Labhane, "<Disappearing and Reappearing Dividends in Emerging Markets.pdf>," Journal of Asia-Pacific Business, 2017.

[10] N. Bhattacharyya, "Dividend policy: a review," Managerial Finance, vol. 33, no. 1, pp. 4-13, 2007.

[11] H. K. Baker, P. H. Kent Baker, D. Rob Weigand, and R. Weigand, "Corporate dividend policy revisited," Managerial Finance, vol. 41, no 2, pp. 126-144, 2015.

[12] N. Dewasiri and W. B. Yatiwella, "Why do companies pay dividends?: a comment," Dewasiri, NJ, Weerakoon Banda. YK, Why Do Companies Pay Dividends, pp. 443-453, 2016.

[13] M. J. Gordon, "<Dividends, Earnings, and Stock Prices .pdf >," The Review of Economics and Statistics, vol. 41, no. 2, p. 99105, 1959.

[14] M. H. Miller and F. Modigliani, "<Dividend Policy, Growth, and the Valuation of Shares.pdf>," The Journal of Business, vol. 34, no. 4, pp. 411-433, 1961.

[15] M. A. Roberto, "Making difficult decisions in turbulent times," Ivey Business Journal, vol. 66, no. 3, pp. 14-20, 2002.

[16] V. Aivazian, L. Booth, and S. Cleary, "<Dividend policy and the organization of capital markets>," Journal of Multinational Financial Management, vol. 13, p. 101 / 121, 2003.

[17] M. Amidu and J. Abor, "<Determinants of dividend payout ratios in Ghana.pdf>," The Journal of Risk Finance, vol. 7, no. 2, pp. 136 - 145, 2006.

[18] H. Ahmed and A. Y. Javid, "Dynamics and Determinants of Dividend Policy in Pakistan.pdf>," Munich Personal RePEc Archive, 2008.

[19] K. Anil and S. Kapoor, "Determinants of dividend payout ratios-a study of Indian information technology sector," International Research Journal of Finance and Economics, vol. 15, no. 1, pp. 63-71, 2008.

[20] D. Al-Kuwari, "<Determinants of the Dividend Policy of Companies Listed on Emerging Stock Exchanges: The Case of the Gulf Cooperation Council (GCC) Countries>," Global Economy \& Finance Journal, vol. 2, no. 2, pp. 38-63, 2009.

[21] A. Gupta and C. Banga, "<The Determinants of Corporate Dividend Policy.pdf $>$," vol. 37, no. 2, 2010.

\section{Published By:}


[22] M. Moradi, M. Salehi, and S. Honarmand, "Factors affecting dividend policy: Empirical evidence of Iran," Business Excellence, vol. 4, no. 1, p. 45, 2010.

[23] T. Afza and H. H. Mirza, "<Ownership Structure and Cash Flows As Determinants of Corporate Dividend Policy in Pakistan>," International Business Research, vol. 3, no. 3, 2010.

[24] N. J. Dewasiri, W. B. Y. Koralalage, A. A. Azeez, P. G. S. A. Jayarathne, and D. K. Weerasinghe, V.A. , "<Determinants of dividend policy evidence from an emerging and developing market.pdf $>, "$ Managerial Finance, vol. 45, no. 3, pp. 413-429, 2019.

[25] H. K. Baker, N. J. Dewasiri, W. B. Y. Koralalage, and A. A. Azeez, $"<$ Dividend policy determinants of Sri Lankan firms a triangulation approach.pdf $>$," Managerial Finance, vol. 45, no. 1, pp. 2-20, 2019.

[26] H. K. Singla and P. K. Samanta, "<Determinants of dividend payout of construction companies a panel data analysis.pdf $>, "$ Journal of Financial Management of Property and Construction, vol. 24, no. 1, pp. 19-38, 2019.

[27] R. E. W. Hudiwijono, S. Aisjah, and K. Ratnawati, "<Influence of Fundamental Factors on Dividend Payout Policy.pdf $>$," Wacana, vol. 21, no. 1, 2018.

[28] R. Gangill and N. Nathani, "<Determinants_of_dividend_policy_A_study.pdf>," IOSR Journal of Business and Management, vol. 2, no. 1, pp. 40-46, 2018.

[29] Y. Yusof and S. Ismail, "Determinants of dividend policy of public listed companies in Malaysia," Review of International Business and Strategy, vol. 26, no. 1, pp. 88-99, 2016.

[30] A. C. Arko, J. Abor, C. K. D. Adjasi, and M. Amidu, "<What influence dividend decisions of firms in Sub-Saharan African.pdf>," Journal of Accounting in Emerging Economies, vol. 4, no. 1, pp. 57-78, 2014.

[31] J. Abor and G. A. Bokpin, "<Investment opportunities, corporate finance, and dividend payout policy: Evidence from emerging markets.pdf $>$," Studies in Economics and Finance, vol. 27, no. 3, pp. 180 - 194, 2010.

[32] H. A. N. Al-Malkawi, "<Determinants of Corporate Dividend Policy in Jordan An Application of the Tobit Model.pdf>," Journal of Economic and Administrative Sciences, vol. 23, no. 2, pp. 44-70, 2007

[33] N. A. Klevmarken, "Panel studies: what can we learn from them?," European Economic Review, vol. 33, pp. 523-529, 1989.

[34] B. Baltagi, Econometric analysis of panel data. John Wiley \& Sons, 2008.

[35] G. A. Akerlof, "<The Market for Lemons Quality Uncertainty and the Market Mechanism.pdf>," The Quarterly Journal of Economics, vol. 84 , no. 3, pp. 488-500, 1970.

[36] S. Bhattacharya, "<Imperfect Information, Dividend Policy, and "The Bird in the Hand" Fallacy.pdf>," The Bell Journal ofEconomics,, vol. 10, no. 1, pp. 259-270, 1979.

[37] B. Brahmaiah, P. Srinivasan, and R. Sangeetha, "<DETERMINANTS OF CORPORATE DIVIDEND POLICY IN INDIA.pdf $>$," Academy of Accounting and Financial Studies Journal, vol. 22, no. 2, 2018.

[38] A. Gill, N. Biger, and R. Tibrewala, "<Determinants of Dividend Payout Ratios Evidence from United States.pdf>," The Open Business Journal, vol. 3, no. 9, 2010.

\section{AUTHORS PROFILE}

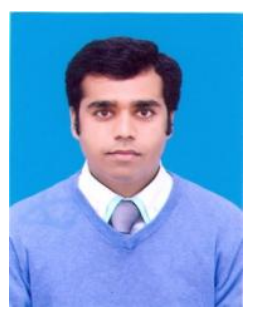

Muhammad Ali Chohan is a $\mathrm{PhD}$ candidate at Universiti Teknologi Malaysia, Malaysia. Chohan received his MBA finance from International Islamic University, Pakistan and BBA Finance from Bahria University, Pakistan. Ali worked as a visiting faculty lecturer at University of Sargodha, Pakistan. His research interests are in the area of corporate finance.

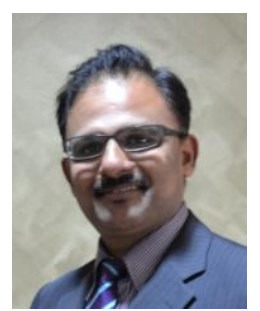

Dr. Suresh Ramakrishnan is a Deputy Dean (Research, Innovation, Development \& Alumni) and an Associate Professor of Finance at Azman Hashim International Business School, Universiti Teknologi Malaysia, Malaysia. Dr. Suresh Ramakrishnan received his Ph.D. in Finance from the Deakin University Australia and held teaching and administrative positions at Universiti Teknologi Malaysia, Malaysia. He has published a number of research articles in the International reputed journals and conference. His research interests are in the area of corporate finance, behavioral finance and corporate social responsibility.

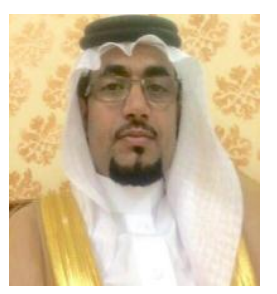

Mr. Saleh Ahmad Al-Harthi is a Ph.D. candidate at Universiti Teknologi Malaysia, Malaysia. Al-Harthi received his M.Sc. in Accounting and Finance on 2011 from Bangor University, UK. He is working as a lecturer at Najran University, Saudi Arabia. His research expertise are corporate finance and behavior finance.

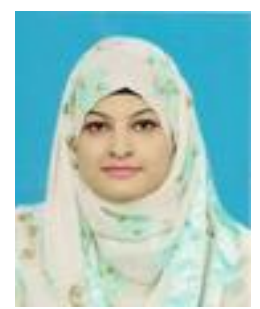

Mrs. Shamaila Butt is a Ph.D. candidate at Universiti Teknologi Malaysia, Malaysia. Shamaila earned her MS in Finance in 2013 from COMSATS University Islamabad, Pakistan. She worked as a lecturer at University of Wah, Pakistan. She has published a number of research articles in the International reputed journals and conference. Her research expertise are financial economics and financial econometrics. 